\title{
Seismic velocity structure in and around the Naruko volcano, NE Japan, and its implications for volcanic and seismic activities
}

Tomomi Okada*, Toru Matsuzawa, Junichi Nakajima, Naoki Uchida, Mare Yamamoto, Shuichiro Hori, Toshio Kono, Takashi Nakayama, Satoshi Hirahara and Akira Hasegawa

\begin{abstract}
Geofluids is important for understanding volcanic and earthquake generation processes. In this study, we obtained a detailed seismic velocity structure in and around the Naruko volcano, northeastern Japan, using data from a dense seismic observation network. We found a distinct seismic low-velocity zone (LVZ) beneath the Naruko volcano, with a diameter of nearly 10 to $20 \mathrm{~km}$ in the lower crust. This LVZ could correspond to a magma chamber. We also found a seismic low-velocity zone beneath the aftershock region of the 2008 Iwate-Miyagi Nairiku earthquake. This LVZ could correspond to an area with overpressurized fluid, which promoted the occurrence of the 2008 Iwate-Miyagi Nairiku earthquake.
\end{abstract}

Keywords: Geofluids; Seismic velocity structure; Seismicity; Naruko volcano; 2008 Iwate-Miyagi Nairiku earthquake

\section{Background}

The Naruko volcano is an active volcano in NE Japan. It has a caldera with a diameter of a few kilometers. The caldera was formed by the eruptions of pyroclastic flows in about $50 \mathrm{ka}$. After the formation of caldera, lava domes were formed in the center of caldera in about $10 \mathrm{ka}$. The Naruko volcano last erupted in 837 and has been recorded as an historical event (Murayama 1978).

Ban et al. (2005) demonstrated that the magma feeding system is composed of a mixture of felsic magma and mafic inclusions. They suggest the presence of a magma chamber beneath the Naruko volcano.

Seismic tomography is an important tool for detecting the presence of magma and other crustal fluids (Julian et al. 1998; Sherburn et al. 2006; Nakamichi et al. 2007; Lees 2007).

Several large- to moderate-sized shallow crustal earthquakes have occurred near the Naruko volcano such as the 1996 Onikobe earthquake (Onodera

\footnotetext{
* Correspondence: okada@aob.gp.tohoku.ac.jp

Research Center for Prediction of Earthquakes and Volcanic eruptions,

Graduate School of Science, Tohoku University, Sendai, Miyagi 980-8578,

Japan
}

et al. 1998; Umino et al. 1998; Nakajima and Hasegawa 2003) and the 2008 Iwate-Miyagi Nairiku earthquake (Okada et al. 2010; Okada et al. 2012). The Naruko volcano is located at the southernmost part of the aftershock area of the 2008 Iwate-Miyagi earthquake. This shallow earthquake and the Naruko volcano are within the Tohoku backbone range strain concentration zone (Miura et al. 2004). The strain concentration zone has possibly formed from crustal softening due to crustal fluid supplied from upwelling magma (Hasegawa et al. 2009). It is necessary to estimate the seismic velocity structure to understand the relation between the crustal fluid distribution and seismic and volcanic activities of the 2008 Iwate-Miyagi Nairiku earthquake and the Naruko volcano.

In this paper, we present the results of seismic tomography, in an area that includes the Naruko volcano and the 2008 Iwate-Miyagi Nairiku earthquake, using data from a dense temporary seismic network and discuss the crustal fluid distribution related to the volcanic and seismic activity. 


\section{Methods}

We deployed a dense seismic network near the Naruko volcano (Okada et al. 2011a; Okada et al. 2013). The network consists of 50 seismic stations. We used an off-line data logger (HKS-9550, Keisoku-Giken, Takanezawa-town, Tochigi, Japan) and a 2-Hz short-period three-component seismometer (CDJ-S2C-2, Chongqing Geological Instrument Factory, Chongqing, China). This network began operations in August 2010, and the average station interval is about a few kilometers around the Naruko volcano.

Waveform data were continuously recorded and digitized at a sampling frequency of $100 \mathrm{~Hz}$ in the WIN-format (Urabe 1994). Timing was corrected through the use of a GPS clock.

Figure 1 shows the station distribution used in this study. Data used in this study was from stations deployed in this study as well as that from the Japan Meteorological Agency (JMA), Hi-net, Tohoku University, and the Japan Nuclear Energy Safety Organization (JNES).
We used manually picked P- and S-wave arrival time data from earthquakes that occurred from 2006 to 2012. Figure 2 shows the hypocenter distribution used in this study. We selected the earthquakes in the area we analyzed from the JMA unified catalog. The number of earthquakes during this period from the JMA unified catalog is 19,191 .

We adopted the seismic tomography method of Zhao et al. (1992). Zhao et al. (1992) uses the pseudo-bending ray tracing method considering the velocity discontinuities and have the advantage to image the deep crustal structure well. The initial velocity structure was from Nakajima and Hasegawa (2003), which is the previous study including the area of this study.

The grid interval is $0.0625^{\circ}$ (about $7 \mathrm{~km}$ ) in the N-S and $\mathrm{E}-\mathrm{W}$ direction. The grid in the depth direction is $0.0,2.5,5.0,7.5,10.0,15.0,20.0,25.0,30.0,35.0,40.0$, $65.0,90.0,120.0,150.0,180.0 \mathrm{~km}$.

We conducted a checkerboard resolution test in order to check the reliability of the result. Based on

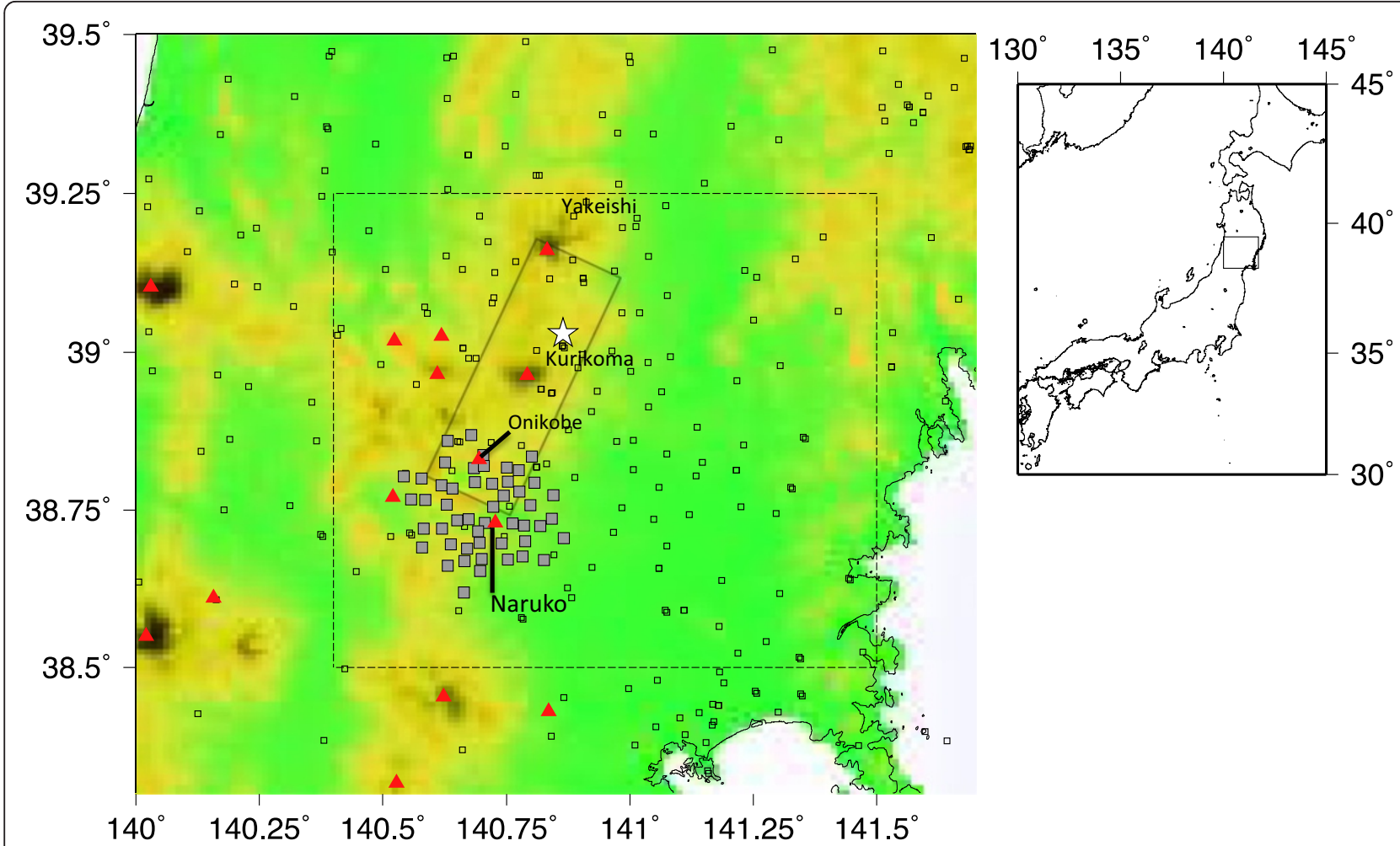

\section{$25 \mathrm{~km}$}

Figure 1 Distribution of stations. Small squares denote the stations used in this study. Gray squares denote the stations deployed in this study. Red triangles are quaternary volcanoes. White star and rectangular with solid lines show the epicenter and the aftershock area of the 2008 Iwate-Miyagi Nairiku earthquake, respectively. Rectangles with broken lines show the area shown in Figure 3. 


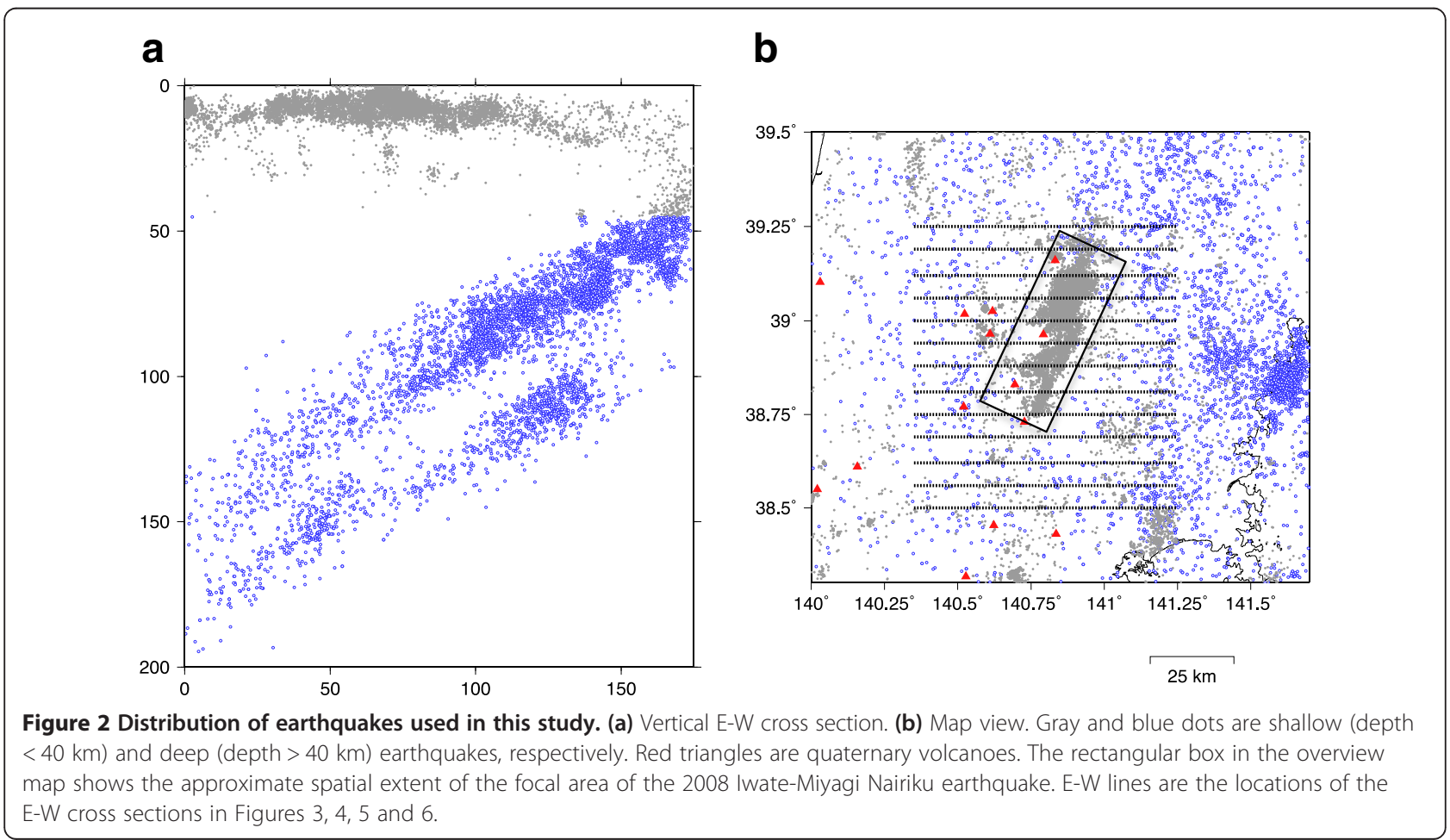

the checkerboard resolution test described in the (Additional file 1), we analyzed the heterogeneity at a scale of $10 \mathrm{~km}$. We also conducted a restoring resolution test (RRT) (Additional file 2), and the result of RRT shows that the velocity structure we have obtained is almost reliable.

\section{Results}

Figure 3 shows the map view of the obtained S-wave perturbation distribution. The seismic velocity structure is complex within the crust, and we found distinct seismic low-velocity zones (LVZs). These low-velocity zones are clearly seen in S-wave perturbation.

In the shallow crust, at a depth of $2.5 \mathrm{~km}$, the LVZ is located beneath each volcano (Naruko, Onikobe, and Kurikoma). The LVZ in the forearc region corresponds to a sedimentary basin.

In the middle to deep crust (10 to $20 \mathrm{~km}$ ), the LVZs can be seen. One is located just beneath the volcanic front, and the other is located in the forearc region. The low-velocity zone at a depth of $10 \mathrm{~km}$ beneath the volcanic front is divided into three or more parts, which are located just beneath the Naruko and other volcanoes. At a depth of $15 \mathrm{~km}$, a LVZ seems to be distributed beneath and around the Naruko, Onikobe, and Kurikoma volcanoes. At a depth of $20 \mathrm{~km}$, a distinct LVZ beneath the volcanic front can be observed. This LVZ seems to be continuously distributed in the NNE-SSW direction, from the Yakeishi to the Naruko volcano. The lateral extent of the LVZ in the NNE-SSW direction is almost the same as the lateral extent of the aftershock area of the 2008 Iwate-Miyagi Nairiku earthquake.

Figures 4, 5 and 6 show the E-W vertical cross sections of the $\mathrm{S}$-wave perturbation, the $\mathrm{P}$-wave perturbation, and the $\mathrm{Vp} / \mathrm{Vs}$ distribution, respectively. Beneath the Naruko volcano, the low-velocity zone in the upper crust has a diameter of about 5 to $10 \mathrm{~km}$. In the lower crust, it is larger and is located slightly to the west. The low-velocity zone in the lower crust is more distinct for S-wave (Figure 4) than for P-wave (Figure 5). This spatial distribution of the LVZ seems to be similar to the high conductive zone found in an MT survey (Asamori et al. 2010).

Beneath the Onikobe volcano, the distribution of the LVZ seems to be similar to that beneath the Naruko volcano.

The seismic low-velocity zone in the forearc side seems to be separated from that in the volcanic front. The 1962 and 2003 northern Miyagi earthquakes are the moderate-sized shallow reverse-type earthquakes in this forearc side (e.g., Mitsuhata et al. 


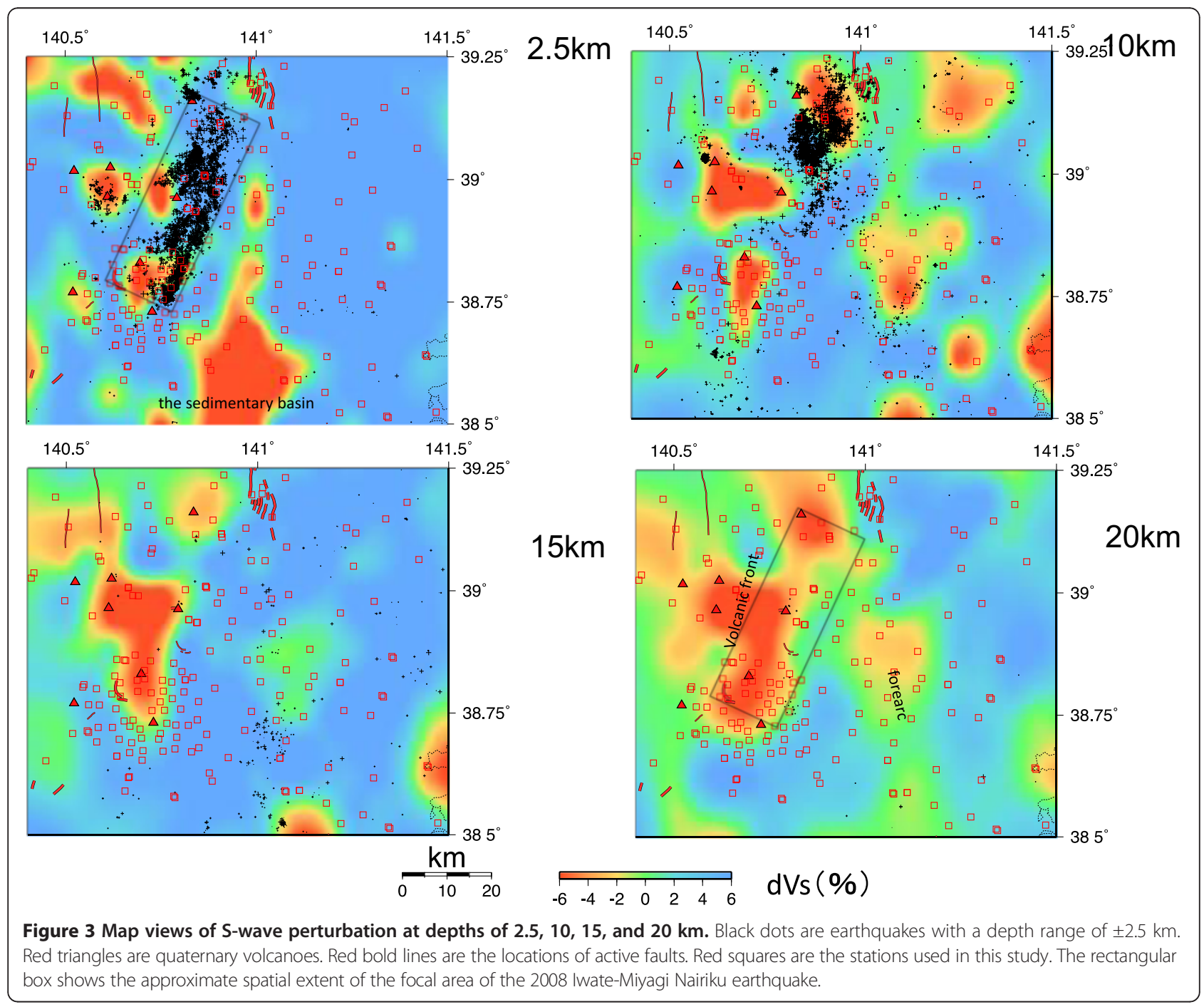

2001; Okada et al. 2007). These LVZs are distributed in and around the focal area of the 1962 and 2003 northern Miyagi earthquakes. An MT survey located an electrical conductivity zone just beneath the fault plane of the 1962 northern Miyagi earthquake (Mitsuhata et al. 2001). Note that the LVZ in the hanging wall of the fault of the 1962 earthquake indicates highly deformed sedimentary rocks as demonstrated in the result of a more detailed tomography study of the 2003 northern Miyagi earthquake (Okada et al. 2007).

In the focal area of the 2008 Iwate-Miyagi Nairiku earthquake, the LVZ is complex and widely distributed beneath the Kurikoma and Takamatsu-dake volcanoes. The major fault plane of the 2008 Iwate-Miyagi Nairiku earthquake is westward-dipping (e.g. Okada et al. 2012) although an eastward-dipping aftershock alignment can be seen. The LVZ in the lower crust is also located on a deep extension of the eastward-dipping aftershock alignment (e.g., E-W cross section along the latitude of 38.8750).

An LVZ is present beneath the Yakeishi-dake volcano even though it is widely distributed in the lower crust.

The $\mathrm{Vp} / \mathrm{Vs}$ distribution shows that the LVZ has a relatively lower $\mathrm{Vp} / \mathrm{Vs}$ in the upper crust as compared to that in the lower crust.

\section{Discussion}

We found many low-V areas. Some of them have low $\mathrm{Vp} /$ $\mathrm{Vs}$ and the others have mid- to high $\mathrm{Vp} / \mathrm{Vs}$. One of the interpretations for low $\mathrm{V}$ and low $\mathrm{Vp} / \mathrm{Vs}$ is the presence of $\mathrm{H} 2 \mathrm{O} / \mathrm{CO} 2$ vapor or water in the pores with small aspect ratio under equilibrium conditions (Takei 2002). The equilibrium condition could be under the low differential 


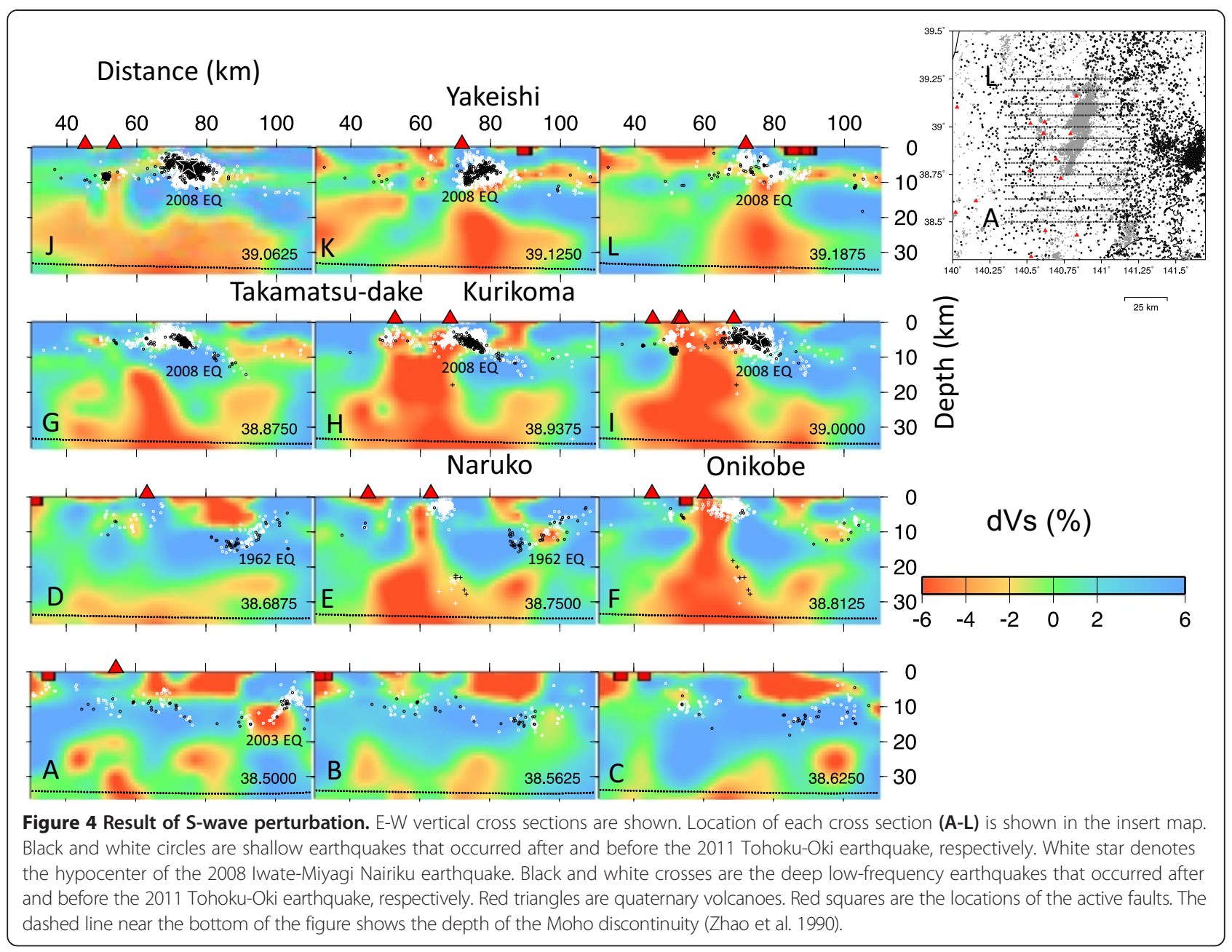

stress. When the fluid is overpressurized and the aspect ratio of pore would be increased, the presence of water in the pores with large aspect ratio increases $\mathrm{Vp} / \mathrm{Vs}$. The presence of melt also increases $\mathrm{Vp} / \mathrm{Vs}$.

Low-V and high-Vp/Vs areas without earthquakes and beneath the volcanoes could be molten magma (Takei 2002; Nakamichi et al. 2007; Lees 2007). The large LVZ in the lower crust beneath the Naruko volcano could be a magma chamber, as suggested by Ban et al. (2005).

There are some small low-V and high- $\mathrm{Vp} / \mathrm{Vs}$ areas in the upper crust, and some of them are aseismic. Low $\mathrm{V}$ and high $\mathrm{Vp} / \mathrm{Vs}$ can be interpreted as in two ways. One is water within the high aspect ratio pore, and the other is the melt. Melt is generally high temperature and is aseismic. The aseismic low- $\mathrm{V}$ and high-Vp/Vs areas just beneath the volcanoes could correspond to an area with molten magma. The absence of seismicity about $5 \mathrm{~km}$ beneath the summit possibly indicates a shallowing of the brittle-ductile transition (B-T in Figure 7).
There are some small low-V and high-Vp/Vs areas with seismicity in the upper crust (e.g., in the crosssection $\mathrm{K})$. Another reason for this low-V and relatively high- $\mathrm{Vp} / \mathrm{Vs}$ area could be the presence of overpressurized fluid (Sherburn et al. 2006; Chiarabba et al. 2009). For a misoriented compressional inversion fault, reduction of fault strength by overpressurized fluid along the fault is a possible cause for reactivation (Sibson 1990; Sibson 2009). The fault plane of the 2008 Iwate-Miyagi Nairiku earthquake is thought to be as compressional inversion fault (Sibson 2009). Compressional inversion fault is the reverse fault along the pre-existing 'normal' fault. The previous study (Okada et al. 2012) showed the complex distribution of the aftershock alignment of the 2008 Iwate-Miyagi Nairiku Earthquake. The complex distribution of the aftershock alignment (i.e., fault) has been spatially correlated with the distribution of the LVZ. Seismic low-velocity zones along and around complex fault planes were 


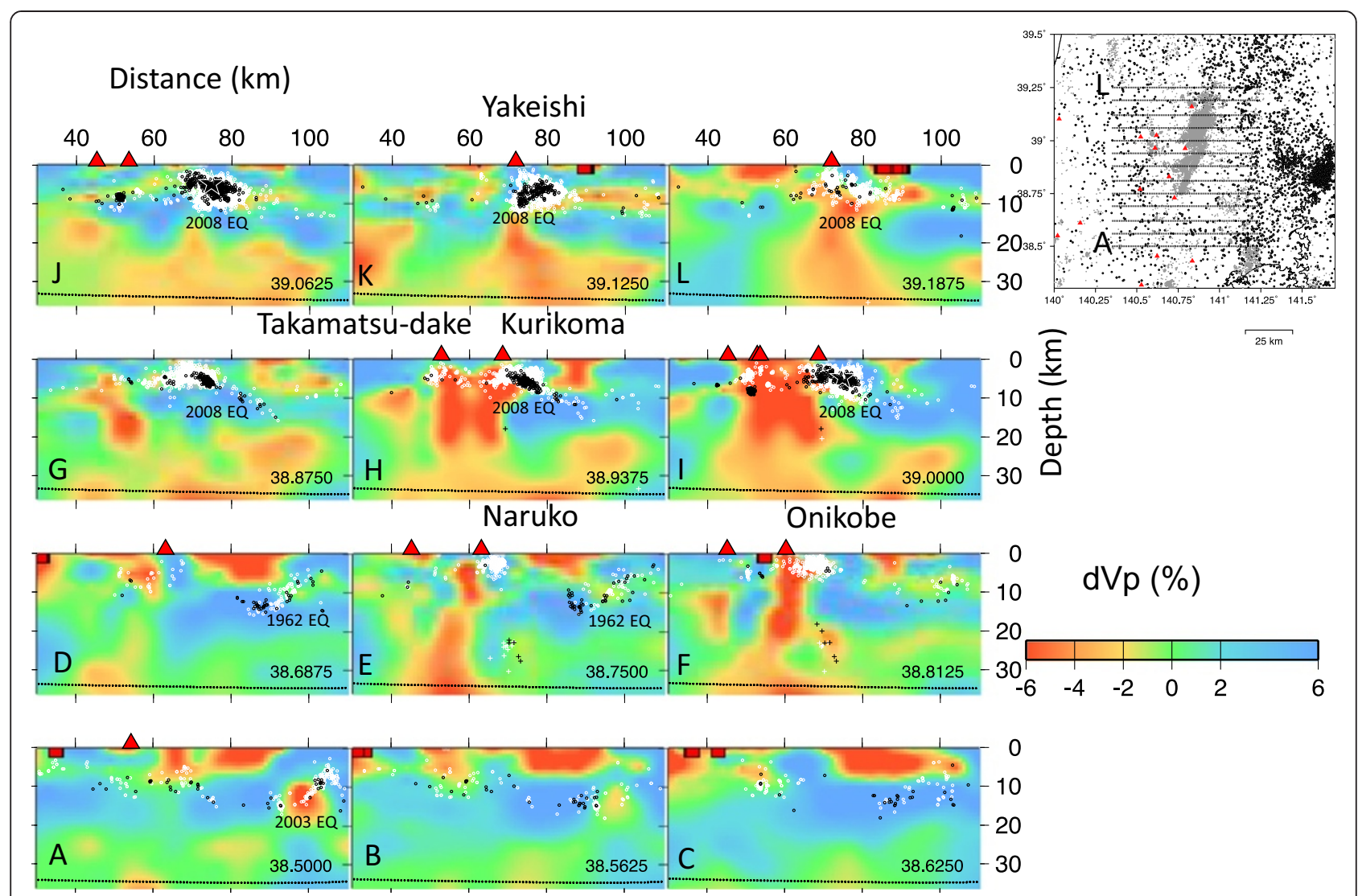

Figure $\mathbf{5}$ Result of P-wave perturbation (A-L). Details are the same as Figure 4.

observed after the 2004 Niigata-Chuetsu earthquake (Okada et al. 2006). This suggests that the fluid path distribution could have controlled the occurrence of the complex faulting during the 2008 Iwate-Miyagi Nairiku earthquake (Figure 7).

There are also low- $\mathrm{V}$ and low- $\mathrm{Vp} / \mathrm{Vs}$ areas in the upper crust. A possible cause of the low $\mathrm{Vp} / \mathrm{Vs}$ in the upper crust is the presence of $\mathrm{H}_{2} \mathrm{O} / \mathrm{CO}_{2}$ vapor released from cooled and solidified magma (Ito et al. 1979; Julian et al. 1998; Takei 2002; Husen et al. 2004; Nakamichi et al. 2007). Another reason could be the presence of water in the pores with small aspect ratio under equilibrium conditions (Watson and Brenan 1987; Takei 2002). This could suggest low differential stress in the low- $\mathrm{Vp} / \mathrm{Vs}$ area. In some of the low-Vp/Vs areas (e.g., $y=38.750, x=80 \mathrm{~km}, z=$ $15 \mathrm{~km}$ in $\mathrm{E}$ of Figure 6), shallow seismicity in the upper crust seems to be absent.

Hori et al. (Hori et al. 2004) observed the later phase in the seismogram from a local earthquake and interpreted it as a reflected S-wave. We also compared the seismic velocity structure with the distribution of S-wave reflectors by Hori and others
(Figure 8). These reflectors are interpreted as fluidfilled thin cracks (Umino et al. 2002) which are distributed in the middle to shallow crust. It seems that the reflectors beneath the volcanoes are shallower. Formation of cracks would be difficult in the ductile regime due to high temperature. Some of the reflectors seem to be in and around the high$\mathrm{Vp} / \mathrm{Vs}$ area and are almost horizontal. These horizontal reflectors could be horizontal veins formed by overpressurized fluid (Sibson 1990).

A change in seismicity occurred after the 2011 Tohoku-Oki earthquake (Okada et al. 2011b). In some areas, the seismogenic stress changed due to the 2011 Tohoku Oki earthquake (Yoshida et al. 2012). In the figures, we plotted the hypocenters before and after the 2011 Tohoku-Oki earthquake in different colors. The earthquakes after the 2011 Tohoku-Oki earthquake occurred in the same areas with the earthquakes before the 2011 Tohoku-Oki earthquake. This suggests that the stress change and/or the fluid pressure change by the 2011 Tohoku-Oki earthquake are not significant for triggering the earthquakes in this region. 


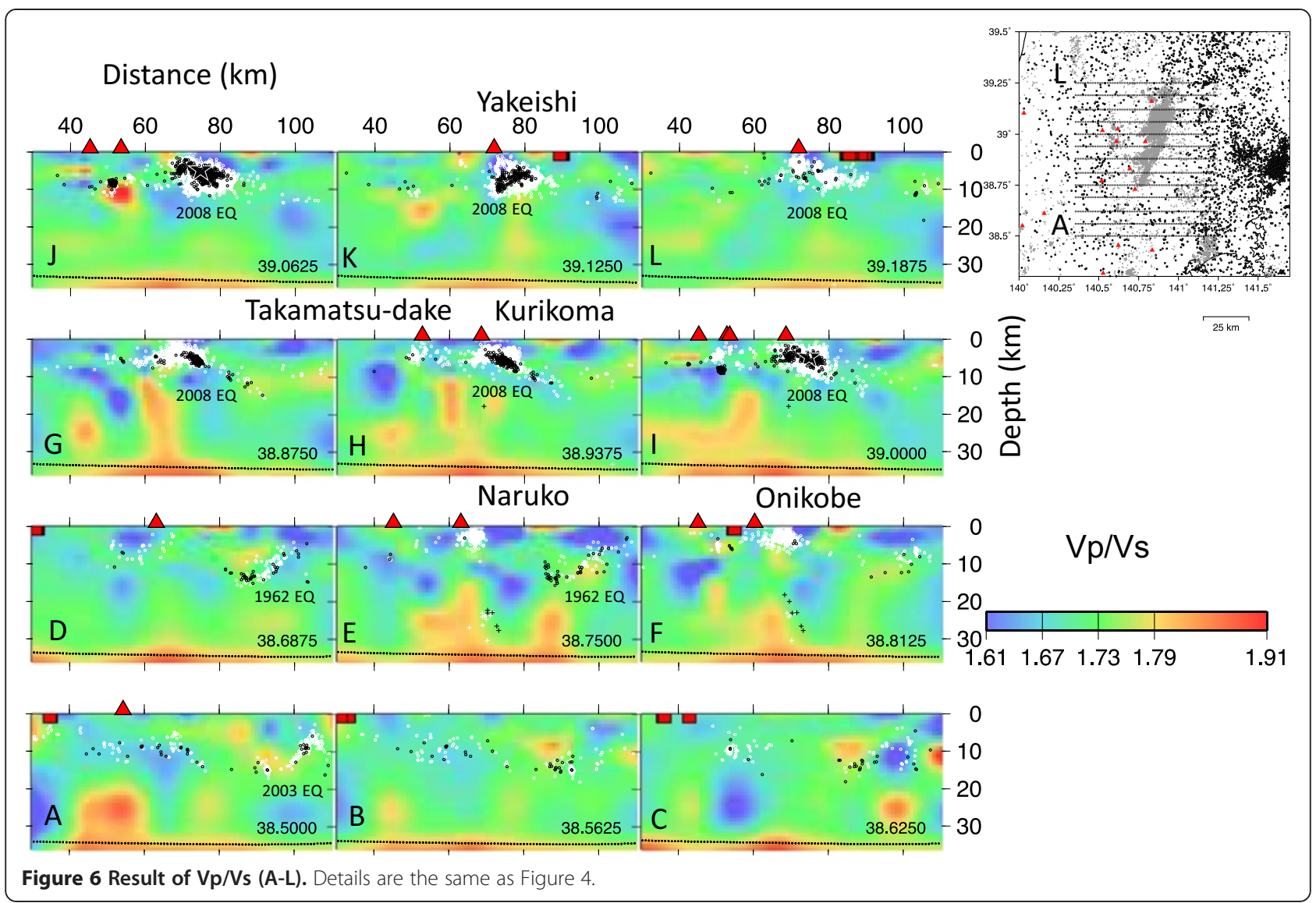

Some earthquakes have occurred in the lower crust beneath volcanoes (e.g., Naruko, Kurikoma, and Yakeishi) at a depth of about $20 \mathrm{~km}$ or greater. These are deep low-frequency earthquakes (Hasegawa and Yamamoto 1994; Okada and Hasegawa
2000). Waveforms from these deep low-frequency earthquakes are relatively complex and are in the frequency range of a few $\mathrm{Hz}$. Deep low-frequency earthquakes are located along the edge of the LVZ with a mid-range $\mathrm{Vp} / \mathrm{Vs}$ in the lower crust. This

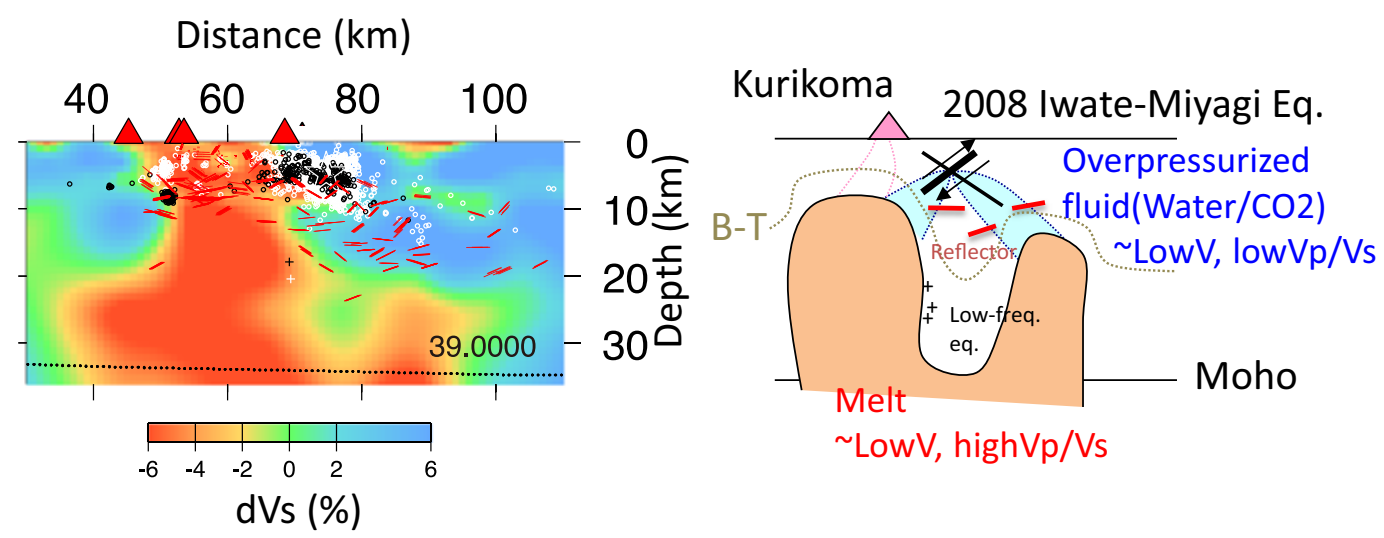

Figure 7 Schematic presentation of the relation between fluid distribution and the complex faulting of the 2008 Iwate-Miyagi Nairiku Earthquake. Brown broken line-labeled B-T shows the brittle-ductile transition. E-W vertical cross section for S-wave perturbation is also shown. See text for details. 


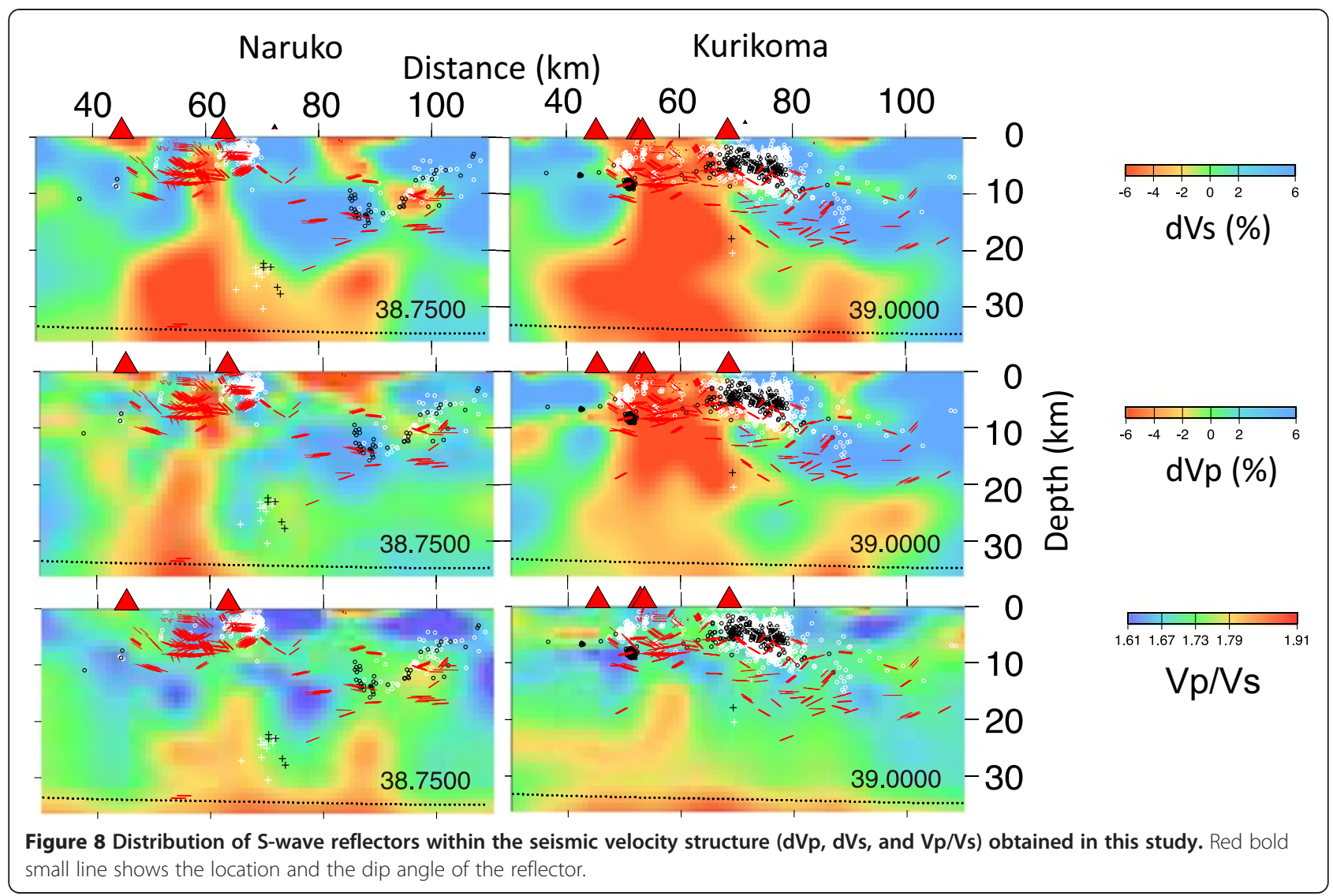

mid-range $\mathrm{Vp} / \mathrm{Vs}$ are interpreted as the area with abundant fluid released from the magma (shown as the LVZ). This suggests that fluid movement from magma could be the cause of these deep low-frequency earthquakes.

Comparison of the derived seismic velocity structure with other geophysical and petrological observations is helpful to understanding the cause of spatial variations in seismic velocity structures. A high conductive zone has been spatially correlated with the distribution of LVZs. Ogawa et al. (2014) also conducted an MT survey in and around the Naruko volcano and found a narrow conductive zone beneath the Naruko volcano. This finding is similar to our observed narrow LVZ beneath the Naruko volcano. Future studies should focus on quantitative interpretation of rock lithology and fluid distribution (Iwamori et al. 2011). A focal mechanism tomography method (e.g., Terakawa et al. 2012) also should be applied to obtain a distribution of fluid pressure.

\section{Conclusions}

Using seismic tomography, we located a distinct seismic low-velocity zone beneath the Naruko volcano. The LVZ has a high $\mathrm{Vp} / \mathrm{Vs}$ in the lower crust suggesting that the LVZ corresponds to molten magma. We also found LVZs in and around the focal area of inland earthquakes. Overpressurized fluid is a possible cause for the LVZ in and around the focal area.

\section{Additional files}

Additional file 1: Figure S1. Result of the checkerboard resolution test for the S-wave. E-W vertical cross sections are shown. Location of each cross section is shown in the insert map. Black and white circles are shallow earthquakes that occurred after and before the 2011 Tohoku-Oki earthquake, respectively. White star denote the hypocenter of the 2008 Iwate-Miyagi Nairiku earthquake. Black and white crosses are the deep low-frequency earthquakes that occurred after and before the 2011 Tohoku-Oki earthquake, respectively. Red triangles are quaternary volcanoes. Red squares are the locations of the active faults. The dashed line near the bottom of the figure shows the depth of the Moho discontinuity (Zhao et al. 1990). Figure S2. Result of the checkerboard resolution test for the S-wave. Details are the same as Figure S1.

Additional file 2: Figure S3. Result of the RRT for S-wave. Details are the same as Figure S1. Figure S4. Result of the RRT for P-wave Details are the same as Figure S1.

Competing interests

The authors declare that they have no competing interests. 


\section{Authors' contributions}

All authors have made substantial contributions to deployment of the seismic stations used in this study. All authors read and approved the final manuscript.

\section{Acknowledgements}

This work was conducted under the support of the Scientific Research Program on Innovative Areas, 'Geofluids: Nature and Dynamics of Fluids in Subduction Zones,' at the Tokyo Institute of Technology (21109002). We used data from JMA and Hi-net/NIED. This study is also a part of the 'multidisciplinary research project for high strain rate zone' promoted by the Ministry of Education, Culture, Sports, Science and Technology (MEXT), Japan. Some of the temporary stations are operated cooperatively with the JNES. We thank Prof. Yasuo Ogawa (TITECH), Dr. Hikaru Iwamori (JAMSTEC), Prof. Michihiko Nakamura, Prof. Tohru Watanabe (Toyama U), Dr. Takash Hoshide (Akita U), Dr. Masaaki Ichiki, Prof. Dapeng Zhao, Prof. Norihito Umino, Prof. Takeyoshi Yoshida, and Prof. Eiichi Takahashi (TITECH) for valuable discussions. We acknowledge the efforts towards seismic observation by T. Sato, K. Tachibana, S. Suzuki, T. Demachi, T. Kaida, and Y. Chiba. The comments by Dr. Toh (the associate editor), and two anonymous reviewers improved the manuscript well.

\section{Received: 14 December 2013 Accepted: 29 August 2014}

Published: 10 September 2014

\section{References}

Asamori K, Umeda K, Ogawa Y, Oikawa T (2010) Electrical resistivity structure and helium isotopes around Naruko volcano, Northeastern Japan and its implication for the distribution of crustal magma. Int J Geophys 2010:1-7, doi:10.1155/2010/738139

Ban M, Takahashi K, Horie T, Toya N (2005) Petrogenesis of mafic inclusions in rhyolitic lavas from Narugo volcano, Northeastern Japan. J Petrol 46:1543-1563, doi:10.1093/petrology/egi025

Chiarabba C, De Gori P, Boschi E (2009) Pore-pressure migration along a normal-fault system resolved by time-repeated seismic tomography. Geology 37:67-70, doi:10.1130/G25220A.1

Hasegawa A, Yamamoto A (1994) Deep, low-frequency microearthquakes in or around seismic low-velocity zones beneath active volcanoes in northeastern Japan. Tectonophysics 233:233-252, doi:10.1016/0040-1951(94)90243-7

Hasegawa A, Nakajima J, Uchida N, Okada T, Zhao D, Matsuzawa T, Umino N (2009) Plate subduction, and generation of earthquakes and magmas in Japan as inferred from seismic observations: an overview. Gondwana Res 16:370-400, doi:10.1016/j.gr.2009.03.007

Hori S, Umino N, Kono T, Hasegawa A (2004) Distinct S-wave reflectors (Bright Spots) extensively distributed in the crust and upper mantle beneath the Northeastern Japan Arc. J Seismol Soc Japan Second Ser 56:435-446

Husen S, Smith RB, Waite GP (2004) Evidence for gas and magmatic sources beneath the Yellowstone volcanic field from seismic tomographic imaging. J Volcanol Geotherm Res 131:397-410, doi:10.1016/S0377-0273(03)00416-5

Ito H, DeVilbiss J, Nur A (1979) Compressional and shear waves in saturated rock during water-steam transition. J Geophys Res 84:4731, doi:10.1029/JB084iB09p04731

Iwamori H, Watanabe T, Nakamura M, Ichiki M, Nakajima J, Ogawa Y, Okada T, Matsuzawa T (2011) An integrated model for mapping geofluids, paper presented at 2011 Fall Meeting. AGU, San Francisco, Calif, 5-9 December 2011

Julian BR, Pitt AM, Foulger GR (1998) Seismic image of a CO 2 reservoir beneath a seismically active volcano. Geophys J Int 133:F7-F10

Lees JM (2007) Seismic tomography of magmatic systems. J Volcanol Geotherm Res 167:37-56, doi:10.1016/j.jvolgeores.2007.06.008

Mitsuhata Y, Ogawa Y, Mishina M, Kono T, Yokokura T, Uchida T (2001) Electromagnetic heterogeneity of the seismogenic region of 1962 M6.5 Northern Miyagi Earthquake, northeastern Japan. Geophys Res Lett 28:4371-4374, doi:10.1029/2001GL013079

Miura S, Sato T, Hasegawa A, Suwa Y, Tachibana K, Yui S (2004) Strain concentration zone along the volcanic front derived by GPS observations in NE Japan arc. Earth Planets Sp 56:1347-1355

Murayama I (1978) The Narugo volcano, volcanoes in Japan (I). Daimeido, Tokyo

Nakajima J, Hasegawa A (2003) Tomographic imaging of seismic velocity structure in and around the Onikobe volcanic area, northeastern Japan: implications for fluid distribution. J Volcanol Geotherm Res 127:1-18, doi:10.1016/S0377-0273(03)00155-0
Nakamichi H, Watanabe H, Ohminato T (2007) Three-dimensional velocity structures of Mount Fuji and the South Fossa Magna, central Japan. J Geophys Res 112:B03310, doi:10.1029/2005JB004161

Ogawa Y, Ichiki M, Kanda W, Asamori K (2014) Three-dimensional fluid distribution around Naruko volcano, inferred from wide-band magnetotelluric measurement. Earth Planets Sp in press

Okada T, Hasegawa A (2000) Activity of deep low-frequency microearthquakes and their moment tensor in northeastern Japan. Bull Volcanol Soc Japan 45:47-63

Okada T, Yagunuma T, Umino N, Matsuzawa T, Hasegawa A, Zhang H, Thurber C (2006) Detailed imaging of the fault planes of the 2004 Niigata-Chuetsu, central Japan, earthquake sequence by double-difference tomography. Earth Planet Sci Lett 244:32-43, doi:10.1016/j.epsl.2006.02.010

Okada T, Hasegawa A, Suganomata J, Umino N, Zhang H, Thurber C (2007) Imaging the heterogeneous source area of the 2003 M6.4 northern Miyagi earthquake, NE Japan, by double-difference tomography. Tectonophysics 430:67-81, doi:10.1016/j.tecto.2006.11.001

Okada T, Umino N, Hasegawa A (2010) Deep structure of the Ou mountain range strain concentration zone and the focal area of the 2008 Iwate-Miyagi Nairiku earthquake, NE Japan — seismogenesis related with magma and crustal fluid. Earth Planets Sp 62:347-352, doi:10.5047/eps.2009.11.005

Okada T, Nakajima J, Uchida N, Yamamoto M, Hori S, Kono T, Nakayama T, Hirahara S, Matsuzawa T, Hasegawa A (2011a) Crustal structure beneath and around the Naruko volcano inferred from seismic observation, Paper presented at Geofluid Workshop 2011. Hanamaki, Iwate, Japan, 17-19 September 2011

Okada T, Yoshida K, Ueki S, Nakajima J, Uchida N, Matsuzawa T, Umino N, Hasegawa A, Group for the aftershock observations of the 2011 off the Pacific coast of Tohoku Earthquake (2011b) Shallow inland earthquakes in NE Japan possibly triggered by the 2011 off the Pacific coast of Tohoku Earthquake. Earth Planets Sp 63:749-754, doi:10.5047/eps.2011.06.027

Okada T, Umino N, Hasegawa A, Group for the aftershock observations of the Iwate-Miyagi Nairiku Earthquake in 2008 (2012) Hypocenter distribution and heterogeneous seismic velocity structure in and around the focal area of the 2008 Iwate-Miyagi Nairiku Earthquake, NE Japan—possible seismological evidence for a fluid driven compressional inversion earthquake. Earth Planets Sp 64:717-728, doi:10.5047/eps.2012.03.005

Okada T, Nakajima J, Uchida N, Yamamoto M, Hori S, Kono T, Nakayama T, Hirahara S, Matsuzawa T, Hasegawa A (2013) Crustal structure and seismicity before/after the 2011 Tohoku-Oki earthquake beneath and around the Naruko volcano inferred from dense seismic observation, Paper presented at the 2013 fall Meet. Seismol. Soc. Japan. Seismol. Soc. Japan, Yokohama, Japan, 7-9 October 2013

Onodera M, Horiuchi S, Hasegawa A (1998) Three-dimensional seismic velocity structure in and around the focal area of the 1996 Onikobe Earthquake Based on Vp/Ns inversion (in Japanese with English abstract). Zisin (Journal Seismol Soc Japan) 51:265-279

Sherburn S, White RS, Chadwick M (2006) Three-dimensional tomographic imaging of the Taranaki volcanoes, New Zealand. Geophys J Int 166:957-969, doi:10.1111/j.1365-246X.2006.03040.x

Sibson RH (1990) Rupture nucleation on unfavorably oriented faults. Bull Seismol Soc Am 80:1580-1604

Sibson RH (2009) Rupturing in overpressured crust during compressional inversion-the case from NE Honshu, Japan. Tectonophysics 473:404-416, doi:10.1016/j.tecto.2009.03.016

Takei Y (2002) Effect of pore geometry on Vp/Vs: from equilibrium geometry to crack. J Geophys Res 107:2043, doi:10.1029/2001JB000522

Terakawa T, Miller SA, Deichmann N (2012) High fluid pressure and triggered earthquakes in the enhanced geothermal system in Basel, Switzerland. J Geophys Res 117:B07305, doi:10.1029/2011JB008980

Umino N, Matsuzawa T, Hori S, Nakamura A, Yamamoto A, Hasegawa A, Yoshida T (1998) 1996 Onikobe earthquakes and their relation to crustal structure (in Japanese with English abstract). Zisin (Journal Seismol Soc Japan) 51:253-263

Umino N, Ujikawa H, Hori S, Hasegawa A (2002) Distinct S-wave reflectors (bright spots) detected beneath the Nagamachi-Rifu fault, NE Japan. Earth Planets Sp 54:1021-1026

Urabe T (1994) A common format for multi-channel earthquake waveform data, paper presented at the 1994 Fall Meet. Seismol. Soc. Jpn. Seismol. Soc. Jpn, Fukuoka, Japan

Watson BE, Brenan JM (1987) Fluids in the lithosphere, 1. Experimentally-determined wetting characteristics of $\mathrm{CO} 2 \mathrm{H} 2 \mathrm{O}$ fluids and their implications for fluid 
transport, host-rock physical properties, and fluid inclusion formation. Earth Planet Sci Lett 85:497-515, doi:10.1016/0012-821X(87)90144-0

Yoshida K, Hasegawa A, Okada T, linuma T, Ito Y, Asano Y (2012) Stress before and after the 2011 great Tohoku-oki earthquake and induced earthquakes in inland areas of eastern Japan. Geophys Res Lett 39: doi:10.1029/201 1GL049729

Zhao D, Horiuchi S, Hasegawa A (1990) 3-D seismic velocity structure of the crust and the uppermost mantle in the northeastern Japan Arc. Tectonophysics 181:135-149, doi:10.1016/0040-1951(90)90013-X

Zhao D, Hasegawa A, Horiuchi S (1992) Tomographic imaging of P and S wave velocity structure beneath northeastern Japan. J Geophys Res 97:19909, doi:10.1029/92JB00603

doi:10.1186/1880-5981-66-114

Cite this article as: Okada et al:: Seismic velocity structure in and around the Naruko volcano, NE Japan, and its implications for volcanic and seismic activities. Earth, Planets and Space 2014 66:114.

\section{Submit your manuscript to a SpringerOpen ${ }^{\circ}$ journal and benefit from:}

- Convenient online submission

- Rigorous peer review

- Immediate publication on acceptance

- Open access: articles freely available online

- High visibility within the field

- Retaining the copyright to your article 